\title{
Reduction of Occupational Risks at Low-Tech Composting Plants in Developing Countries - Case Study ENPRO Composting Site LomÉ, Togo
}

\author{
Daniela Bleck ${ }^{1}$, Edem K. Koledzi ${ }^{2}$, Hélène Bromblet ${ }^{3} \&$ Gnon Baba $^{2}$ \\ ${ }^{1}$ Federal Institute for Occupational Safety and Health, Dortmund, Germany \\ ${ }^{2}$ Laboratory GTVD of University of Lomé, Lomé, Togo \\ ${ }^{3}$ Gevalor, Olivet, France \\ Correspondence: Daniela Bleck, Federal Institute for Occupational Safety and Health, D-44149, Germany. \\ E-mail: bleck_daniela@gmx.de
}

Received: May 6, 2013 Accepted: May 23, 2013 Online Published: June 13, 2013

doi:10.5539/jsd.v6n7p26 URL: http://dx.doi.org/10.5539/jsd.v6n7p26

\begin{abstract}
Manual sorting and composting of mixed municipal household waste is associated with occupational hazards. This case study aimed at finding sustainable solutions to alleviate occupational risks for workers at a composting site in Lomé, Togo and at demonstrating a pragmatic way to apply international safety standards to composting facilities in developing countries.

Occupational risks were assessed by means of onsite data collection and workshops and interviews with workers and management representatives. The data were the basis for the evaluation of the risk as a function of "Severity of the potential harm" and "likeliness that harm is done".

Mixed household waste is delivered to the composting plant. Pre-sorting and sorting non-decomposable residuals out is time consuming and requires a large number of workers. During all compost production procedures, workers are exposed to pathogen containing dust, experience musculoskeletal burdens due to handling heavy loads and face the risk of cuts caused by sharp items. Adverse environmental conditions increase occupational risks. Delivery of the organic waste fraction separated at household level is recommended toomit risky work steps and to increase process efficiency. For the current mode of operation, we present process re-engineering options and organisational measures to reduce occupational risks and we discuss implementation constraints.
\end{abstract}

Keywords: composting, waste sorting, occupational safety and health, developing countries, process re-engineering, Lomé (Togo)

\section{Introduction}

In Lomé, the capital of Togo, dealing with large amounts of solid wastes is a challenge. Large quantities of mixed household wastes are burnt or illegally dumped. Environmental pollution, adverse public health impacts and climate affecting emissions are the consequences. On the other hand, sandy soils in Lomé's surroundings are nutrient poor and productive farming requires the application of fertilizers. Household waste of Togo contains a high proportion of organic, decomposable material which can be converted into compost. Implementing a household waste collection system and the valorisation of organic waste by compost production mitigates the negative effects above and new jobs are created.

ENPRO - "Ecosystème Naturel Propre" is an NGO created by a group of university graduates in 1999. It is dedicated to contributing to the cleanliness of the city of Lomé, Togo, through household waste collection and valorisation of organic materials by composting. In collaboration with the French association GEVALOR, the CEFREPADE and Laboratory GTVD of Lomé University and with French funds, a compost site was constructed in north-western suburb of Lomé, close to the border to Ghana. It was officially inaugurated in February 2011 and processed $5 \mathrm{t}$ of waste per day since. Shortly before the conduct of this study, production was increased to $10 \mathrm{t}$ of delivered waste per day (Gevalor, 2011). In order to provide income opportunities for many persons, all compost production processes, sorting of input material, turning the compost piles and sieving and packing procedures are performed manually.

In 1948, the United Nations adopted the Universal Declaration of Human Rights. Article 23 states: 
"Everyone has the right to work, to free choice of employment, to just and favourable conditions of work and to protection against unemployment" (United Nations, 1948). Just and favourable working conditions include the right to physical and mental health and the protection thereof. International as well as national bodies of most countries have developed or are in the process of developing legislation and strategies to protect the health of workers at their workplace, following the maxim that work related accidents have to be prevented rather than cured (ILO, 1981). According to Togolese national legislation, it is the obligation of an employer to prevent occupational risks and to provide occupational safety and health services (Republique Togolaise, Ministère du travail, de l'emploi et de la sécurité sociale, 2006). All employees have to be registered with the national social security system (Republique Togolaise, Ministère du travail, de l'emploi et de la sécurité sociale, 2011). The social security system entails family and maternity payments, retirement funds as well as a occupational risk insurance (article 2, ibid.). The occupational risk insurance covers medical costs, compensation for temporary and permanent disability due to accidents and diseases acquired at the workplace as well as on the way to and from work (articles 48-73, ibid.). Implementation of these regulations, however, is not yet satisfactory due to the informal character of the Togolese economy.

Manual composting processes are associated with occupational safety and health risks. Household waste contains a large percentage of organic, decomposable materials, such as kitchen and garden wastes. These wastes are covered with a film of micro-organisms which live and feed on the organic material, thus playing an important role as destruents in the decomposing process. When micro-organisms become a substance which is handled in the occupational context, they are called biological agents. Biological agents are (parts of) bacteria, fungi, endoparasites and protozoae that cause a potential risk to human health in form of infections, diseases and allergies. Though, strictly speaking, they are not living organisms, viruses and metabolites from micro-organisms, so called endotoxins, are also grouped in this category and are classified into risk groups according to their level of risk of infection by European Commission (2000).

Endotoxins produced by gram-negative bacteria can cause mucous membrane irritations, immunitoxic and allergic diseases, gram positive bacteria are responsible for infections, e.g. Tetanus. Inhalation of spores and hyphal fragments of funghi causes allergies, especially allergic alveolitis and immunotoxic diseases (organic toxic dust syndrome), ingestion invokes gastro-intestinal problems. Filamentous actinomycetes produce strong allergens causing allergic alveolitis, skin infections or epidermic eczema. Aspergillus spp. is the main pathogen in the waste management sector causing mycosis (fungi induced infections) and allergies (Dutkiewicz, 1997; Nielsen et al., 2008; Malmros et al., 1992; Swida, 1999; Riege, 1999; Ivens et al., 1999).

Workers collecting or composting organic waste in developed as well as in developing countries reported respective symptoms (Groner-Weber, 1999; van Eerd, 1997; Heldal \& Wijnand, 2004; Gladding et al., 2003) which are also common in other working environments where workers are exposed to high levels of bioaerosols (Heldal et al., 1997).

Injuries from sharp objects due to the handling of waste are common (e.g. Yang et al., 2001) and bear the risk of Tetanus and Hepatitis B infections as waste workers in developing countries are usually not vaccinated (van Eerd, 1997). Lifting, carrying and shoveling activities are associated with musculoskeletal burdens (Cointrau, 2006; Bundesministerium fuer Arbeit und Soziales, 2006). Moreover, sorting mixed household waste and external emission sources can be responsible for exposure to hazardous substances.

Managing these risks is not only a legal requirement. A healthy workplace sustains the social benefits intended with the project. However, European standards to reduce occupational risks at composting plants are not applicable at ENPRO's composting facility. An occupational safety and health study was performed to identify occupational risks at ENPRO's composting plant and to develop sustainable, feasible counteractive measures. Finding solutions which are adapted to the local preconditions, technical level and available financial resources was one goal of the authors. We considered experiences and approaches developed in a solid waste management project called IGNIS "Income Generation and Climate Protection by Valorising Municipal Solid Wastes in an Emerging Megacity, Exemplarily for the City of Addis Ababa, Ethiopia". This paper aims at demonstrating a pragmatic way to apply global safety standards to small scale composting facilities in developing countries. Furthermore, factors influencing the feasibility of the suggested measures and experiences with implementation are discussed.

\section{Methods}

\subsection{Risk Assessment}

Depending on working procedures, working environment and especially the precise activities executed, a worker is exposed to different health and safety hazards. Risk assessment is the process of finding and evaluating risks 
to workers' safety and health. It is the central part of occupational safety and health management since it enables the employer (as well as the employee) to fully understand the workplace related hazards and to derive efficient preventive measures.

A risk assessment at ENPRO compost site was carried out following a methodology developed for the IGNIS project (IGNIS consortium, 2011). Compost production comprises different processes, e.g. waste delivery, setting up compost piles and packing the final product. Each process was observed and divided into different activities to identify risk sources. Risk data were collected for the categories musculoskeletal burdens, biological agents (exposure to microorganisms), hazardous substances, mechanical risks, fire, noise, electrical risks, (UV)-radiation, animals as well as general working conditions and hygiene practices. For each category, detailed data assessment sheets were applied. They contained questions regarding the potential severity of the harm, e.g. characteristics of the risk source (properties of handled materials, weight) and affected body parts as well as factors required to evaluate the likeliness that harm is done, e.g. exposure time and height, additional factors contributing to exposure (e.g. workplace and process characteristics), experienced incidents and coping mechanisms. Since the timeframe for this study was limited, not all of the parameters could be assessed in detail. In some cases weights, repetitions and exposure times had to be estimated.

Risk of physical overload was evaluated with the "Key Indicator Method for Activities Involving Lifting, Holding, Carrying" (Bundesanstalt fuer Arbeitsschutz und Arbeitsmedizin, 2001). For the other categories, the risk had to be evaluated by estimating the potential severity of harm that can result of interaction between hazard and worker and the likeliness that harm is done. Based on existing evaluation matrices, by IVSS (1997), Gruber et al. (2008), Nohl (1988) a simplified matrix was developed and applied. The severity of harm was assigned to one of three classes "low", "medium" or "high" according to curability of the injury/disease and lost working time. Likeliness that a hazard could cause harm was classified as "improbable/rare", "possible" and "very probable" depending on the exposure determinants. The results of the matrix application are grouped into three classes "high", "medium" and "low" risk. A high risk should be counteracted immediately and medium risks should be reduced in the near future.

Participatory workshops and interviews with the employees were performed to find out existing occupation related health problems as well as safety concerns of the workforce. We used Participatory Rapid Appraisal strategies (Chambers, 1994) with group discussions and ranking exercises to find out the worker's highest safety and health concerns. Management interviews addressed decision rules for the choice of the current composting methods as well as operational and financial constraints.

\subsection{Development of Safety Interventions}

Safety interventions should be developed by following an internationally acknowledged hierarchy. Elimination of the hazard at its source, e.g. by substituting hazardous chemicals or omitting burdensome work-steps renders additional measures unnecessary and is thus the most efficient precautionary intervention. Collective protective measures such as safer machinery and appropriate work organization are to be preferred to individual measures like personal protective equipment and training in appropriate behaviour. The latter do not combat the hazard itself but only provide a barrier between hazard and worker at the ultimate point. Since it is very difficult to change people's behaviour, they are less effective and should only be applied if the former interventions do not suffice (European Economic Community, 1989).

At composting plants it is not possible to substitute the input material to reduce occupational risks. Waste is the source of income and the central constituent of all workplaces. Therefore we aimed at substituting operational procedures which provoke a risk.

Safety interventions were developed based on the risk assessment results and the information gained during worker and employer interviews/workshops. Additionally, an onsite brainstorming session was performed during which the workers contributed their ideas for safety and health improvements. The derived safety interventions were discussed with the management of ENPRO with regard to feasibility.

\section{Findings and Discussion}

\subsection{Processes}

ENPRO's compost site is located close to the border with Ghana next to a residential neighbourhood. Mixed waste is delivered by trucks or trailers and unloaded onto the eastern end of a concrete platform of $76.5 \mathrm{~m} \mathrm{x} 15 \mathrm{~m}$ which is covered with a corrugated iron roof (Koledzi et al., 2012). In a pre-sorting work step, large non-decomposable items are removed and loaded onto wheelbarrows or 200-1 drums for disposal. To fill the buckets or wheelbarrows, workers place them between their legs and pull the material inside. 
The organic fraction to be sorted more thoroughly is shovelled into a wheelbarrow. The wheelbarrow is pushed up a narrow ramp and contents are skipped onto the sorting table (height ca. $1.10 \mathrm{~m}$ ). At each side of the table, 4 persons sort the waste in two steps by negative sorting. The first two persons take the larger non-decomposable items out and shove the waste further to the next pair of sorters by use of small wood panels. Finer items are taken out by the second team. Each sorter throws residual waste into a drum placed aside. The sorted fractions are pushed with panels into a wheelbarrow positioned at the end of the table. Shifting the waste along the table is required to obtain good sorting results and to allow for residual sand to fall through the holes in the table onto the floor. Sorting is performed daily.

After sorting, one worker pushes the wheelbarrow to the location of the pile, skips its contents and shapes the pile with a hayfork or shovel. After increasing the amount of input waste the space under the roof does not suffice anymore and piles are also placed onto natural ground next to the platform. During the composting process each pile is manually turned seven times.

At the end of the process, the compost is sieved and packed. One person fills the matured compost into a large bucket. A second person carries the bucket to the sieve and empties it. Carrying distances depend on the location of the pile and do not exceed $50 \mathrm{~m}$. Two to three persons spread the material with small old wood panels on the horizontal metal sieve. Compost falls through the sieve straight onto the floor. Residuals are manually transferred into buckets and disposed of at the nearby wild dump. After sieving, the workers shovel the compost into buckets and empty them onto the large storage pile. In case of an order, they fill the compost into buckets to measure the quantity. Then the buckets are emptied into rice straw bags held open by two co-workers.

All residual waste is carried in bins to a wild dump in the vicinity which is also used by the local population to dispose of household waste. A secondary collection company occasionally clears the dumpsite. Residual sand is collected and disposed at a separate location.

\subsection{Occupational Risks}

The dumpsite used for residual waste disposal self-ignites or is set on fire by residents. Hence, workers at ENPRO's compost site are exposed to toxic emissions of the fire many days of the year, throughout the entire day. The wind blows the fumes towards the compost platform most of the time due to a rather constant unfavourable wind direction. Workers disposing of residual waste are particularly exposed to these fumes due to close proximity to the source of emissions. Table 1 compiles the risk evaluation results on process level.

Walking around the platform, especially while carrying heavy loads, is difficult and bears the risk of tripping and falling accidents due to accumulated waste between the compost piles and the lack of defined walk ways. Ants are often found and might cause skin irritations.

Table 1. Occupational risks

\begin{tabular}{llllll}
\hline & $\begin{array}{l}\text { Pre- } \\
\text { sorting }\end{array}$ & Sorting & Piling & Turning & $\begin{array}{l}\text { Sieving, } \\
\text { packing }\end{array}$ \\
\hline Hazardous substances & high* & high* & high* & high* & high* \\
Musculoskeletal disorders & medium & medium & low & high & low \\
Biological agents & high & high & medium & high & low \\
Mechanical risks & medium & medium & medium & low & medium \\
Animals & low & low & low & low & low \\
\hline
\end{tabular}

*environmental cause of exposure.

Workers involved in pre-sorting and sorting are highly exposed to organic dust. Musculoskeletal burdens due to handling heavy loads are likely to occur as large amounts of waste are shovelled, carried and pushed with wheelbarrows. Workers who carry residual waste in 200-1 barrels over ca. 100-m distance to the dumpsite ca. 35 times per day experience the highest burdens. Evaluation with the Key Indicator Method (Bundesanstalt fuer Arbeitsschutz und Arbeitsmedizin, 2001) revealed a "highly increased load situation, physical overload also possible for normal persons. Redesign of the workplace is recommended. Disposal of residual sand is associated with additional physical burdens and dust generation. 
Setting up the compost piles is associated with tripping and falling risks and exposure to biological agents. Limit values for physical burdens are not exceeded when considering this process only.

Piles are turned on the spot, a fixed displacement scheme does not exist. This procedure is positive with regard to musculoskeletal burdens as displacement distances are reduced. However, manual shovelling for several hours is associated with unfavourable body posture and exerts strains on muscles and joints of upper limbs. Repeated bending and twisting the trunk has negative effects on lower back muscles and spine. Since the material is compacted and hard at the point of turning, the pile is "broken open" by use of pickaxes. The material is displaced by pulling it between the legs of the worker in the same step. Ergonomically efficient, this method involves inhalation exposure to pathogen containing dusts and vapours. Wind blowing from an unfavourable direction or turning two piles located next to each other at the same time increases exposure.

Sieving and packing of mature compost is associated with high inhalation exposure to dust due to dryness of material while emptying bins and spreading material on the sieve. The risk of musculoskeletal disorders was within daily limits for the situation observed but is likely to exceed limits if larger quantities of compost are processed or if the workers who carry material from the pile to the sieve or from the sieve to the dump site are also involved in other disposal activities.

During the workshop, the workers identified and prioritized the following problems: 1) Stomach problems due to exposure to the "smell of the waste" especially during pre-sorting, sorting and turning the piles. 2) Lower back pain caused by heavy physical work and permanent standing. 3) "Heart problems" due to exhaustion. They further mentioned headache and knee problems. Respiratory problems were attributed to exposure to dust and dumpsite fire emissions. Fourteen workers with an average age of twenty-six years (mean and median) participated at the workshop. The youngest was twenty-one, the oldest forty-five years old. They worked at the composting plant for half a year to a year.

\subsection{Safety Interventions}

Today, ca. $40 \%$ of the collected waste is sand and $30 \%$ is non-decomposable refuse. Sorting and disposing these $70 \%$ of the waste consumes the highest amount of working time and man-power at the composting site and is associated with high physical burdens and inhalation exposure to organic and inorganic dust. An efficient measure with positive effects on occupational safety as well as on compost plant productivity would be waste separation at household level. With the delivery of the organic fraction to the composting site only, the pre-sorting process can be omitted and sorting time at the sorting table can be reduced (Figure 1). This leads to a reduction of exposure to biological agents and sharp items.

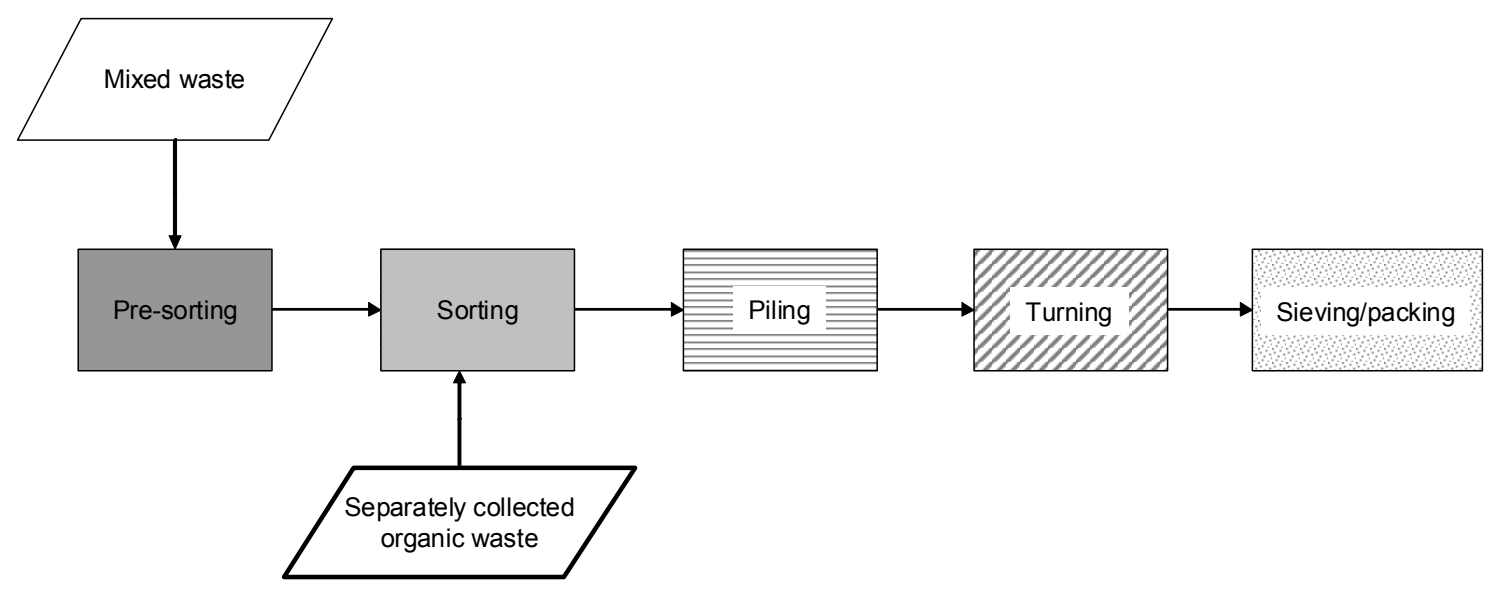

Figure 1. Effects of separate waste collection on compost production process chain

Considering that today seven tons of waste are disposed and acknowledging that separate collection will not be $100 \%$ efficient, the daily amount of waste to be disposed would supposedly be reduced by ca. five to six tons which would not have to be shovelled, lifted, carried and dumped.

Figure 2 indicates schematically how process duration would be affected by separate household waste collection. 


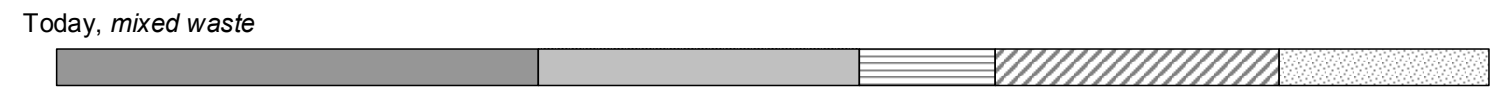

Separate Collection, same quantity of organic material as today

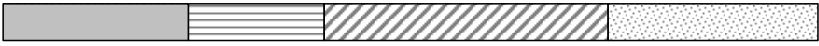

Separate Collection, same quantity of waste as today but $85 \%$ organic

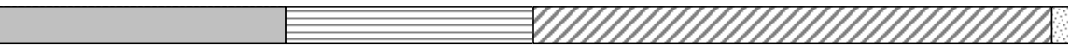

Figure 2. Time allocation to composting processes depending on household waste collection method, Colour scheme according to Figure 1

In comparison with the situation today (top row), separate collection of the same amount of organic waste as today would reduce total compost production time (middle row).

Installing and running separate collection supposedly requires more man-power than mixed waste collection as the collection procedures need to be modified, households trained and sorting efficiency monitored. Work force set free at the compost plant in case of a separate waste delivery have the required knowledge of waste sorting and would hence be qualified to perform these new tasks. Alternatively, the workers occupied with sorting today could process a larger quantity of organic waste delivered after separate collection. So, space capacity permitting, the productivity of the site would be increased (bottom row of Figure 2). Due to a higher amount of input material, the processes "piling", "turning" and "sieving and packing" would be intensified. Risks associated with these work steps need to be minimized with adequate measures. A feasibility study on separate household waste collection is currently being carried out.

Since installation of a well running separated household waste collection scheme requires time and can be considered a long-term intervention, we also developed safety measures for the current procedures with mixed waste delivery.

In the worst case scenario with wind blowing from the dumpsite towards the plant, workers are exposed to toxic emissions from the dumpsite fire all day. While extinguishing the fire is accomplishable, preventing re-ignition is more difficult. First, it is likely that the surrounding populationwho is used to burning waste as a means of waste management sets the waste deliberately on fire. Second, self-ignition of the waste is possible in Lomé's climate. A better option to avoid dump fires is to decide for another disposal strategy (which would also protect the environment), e.g. the utilization of a container that will be picked up by secondary collectors and emptied at a municipal dumpsite.

Additional manual waste transfer steps need to be limited as much as possible in order not to create new occupational risks in form of additional exposure to waste dusts and physical overload. One option is to excavate a pit for a container or truck/trailer. Residual waste transported in a wheelbarrow can be dumped by gravitation without any additional physical effort. Dimensions of the pit and the inclinations of access ways depend on the container/trailer used for refuse collection.

Another possibility is the construction of a ramp and a platform at the compost site according to Haan et al. (1998). The highest point of the container and the platform of the ramp should be almost level to facilitate disposal. Dimensions need to be calculated for the respective situations. DIN 2002 (Deutsches Institut fuer Normung, 2002) provides force limits to be considered for calculation of ramp inclination. In case of one person pushing a wheelbarrow with a weight of $100 \mathrm{~kg}$ a slope of $9^{\circ}$ should not be exceeded (Bleck \& Wettberg, 2012). Ideally waste is delivered onto the elevated platform. Pre-sorting workers sort contraries out and shovel them downwards into the container or truck. Waste to be transferred to the sorting table can be dumped into a wheelbarrow placed on the ground at another side of the platform. The platform can even be perforated and equipped with a cavern to allow sand to fall through the holes of the platform straight into a wheelbarrow. This way, physical burdens caused by shovelling sand and residuals into a wheelbarrow will not occur and exposure to dust will be reduced since the roof of the cavern prevents dust from rising to the respiratory tract of the worker.

Figure 3 compares the new scenarios with the current procedure for the treatment of residual waste. Pre-sorting on the ground and transporting residuals with a wheelbarrow over the ramp to the container (scenario 1) does not alter the treatment procedures of organic waste and sand and does, hence, not alleviate physical burdens or exposure to dusts during pre-sorting. Its major advantage is that a container instead of the wild dump is used for 
residual waste disposal and compost site workers are not exposed to fire emissions from and at the wild dump anymore. In scenario 2, work steps "shovelling waste into a wheelbarrow" and "pushing the wheelbarrow up a ramp" with their respective hazards are omitted and, hence, occupational risks for pre-sorters are reduced.

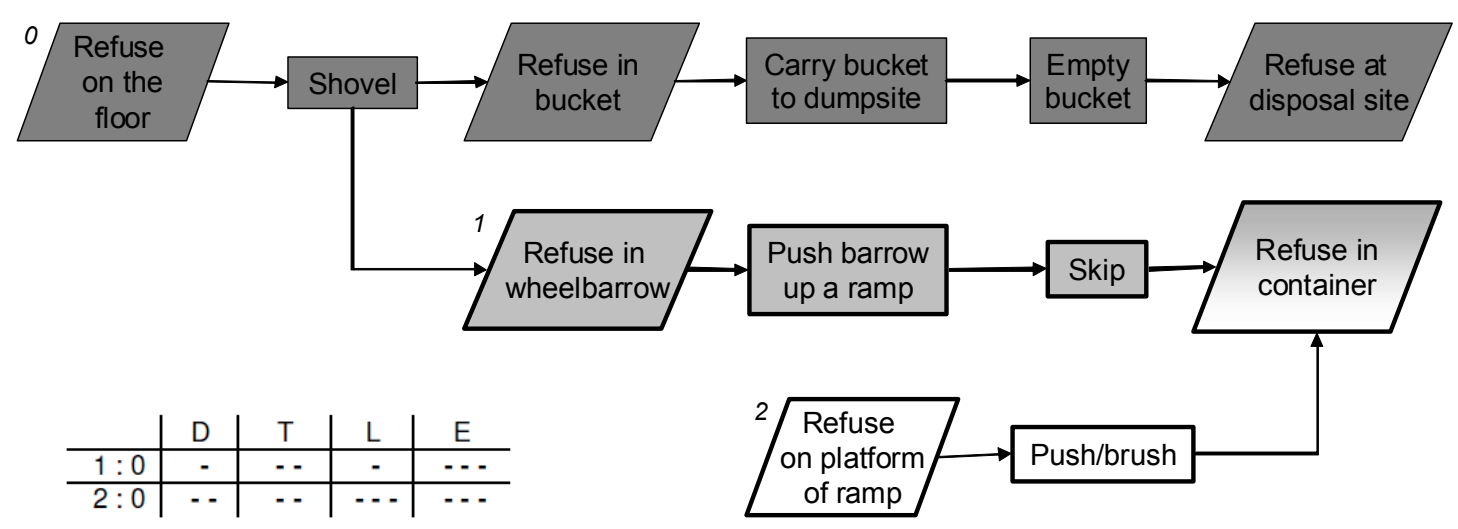

Figure 3. Current and suggested residual waste disposal procedures after pre-sorting

0-2: Scenarios. $\mathrm{D}=$ Dust emissions, $\mathrm{T}=$ Tripping and falling risk, $\mathrm{L}=$ Physical load $\mathrm{E}=$ Exposure to emissions of dumpsite fire. Qualitative comparison of risk reduction between scenarios: “-”: reduced; "- -": much reduced, “. - .": very much reduced.

Any of these solutions can also be used for the transferral of residual waste to be disposed of after sorting and sieving. The ramp can also facilitate loading a truck with mature compost for sale. In hilly areas the ramp concept can be further refined by taking advantage of the topography (Haan et al., 1998). The terrain can be modelled into terraces to allow for sorting to be performed on the upper terrace and the waste to be shovelled into the container placed on the lower terrace. However, organising the collection of the residual waste container by the municipality or a contractor is expected to pose a constraint due to a current lack of communication between the different stakeholders and potential costs.

Management interviews revealedthat ENPRO, who also performs household waste collection, has a high stake at finding solutions to keep the sand out of the waste at household level to avoid high transportation costs as well as disposal efforts at the composting facility. Options for solutions have been analysed and discussed by Ale et al. (2007) and the implementation of the suggested solutions, at first as a pilot test, is highly recommended also with regard to occupational safety and health. This is another example of how process efficiency and safety at work go hand in hand.

Minor constructional measures can facilitate the disposal of residual sand at the sorting table. Sand can be directed with a funnel straight into a wheelbarrow and continuously transported to the sand dump (Figure 4). The funnel can either be a fixed iron construction or a plastic foil/textile sheet attached to the sorting table.

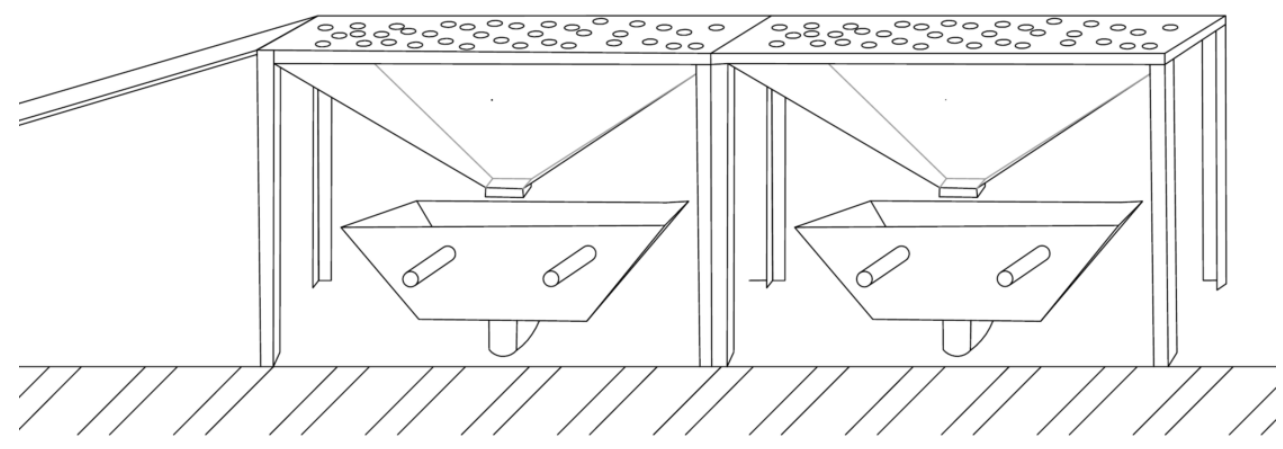

Figure 4. Easier sand disposal 
With this measure, strenuous shovelling of heavy sand in awkward posture from under the table into wheelbarrows is omitted as illustrated in Figure 5. Filling the wheelbarrow with sand is no more associated with physical load and exposure to dust.

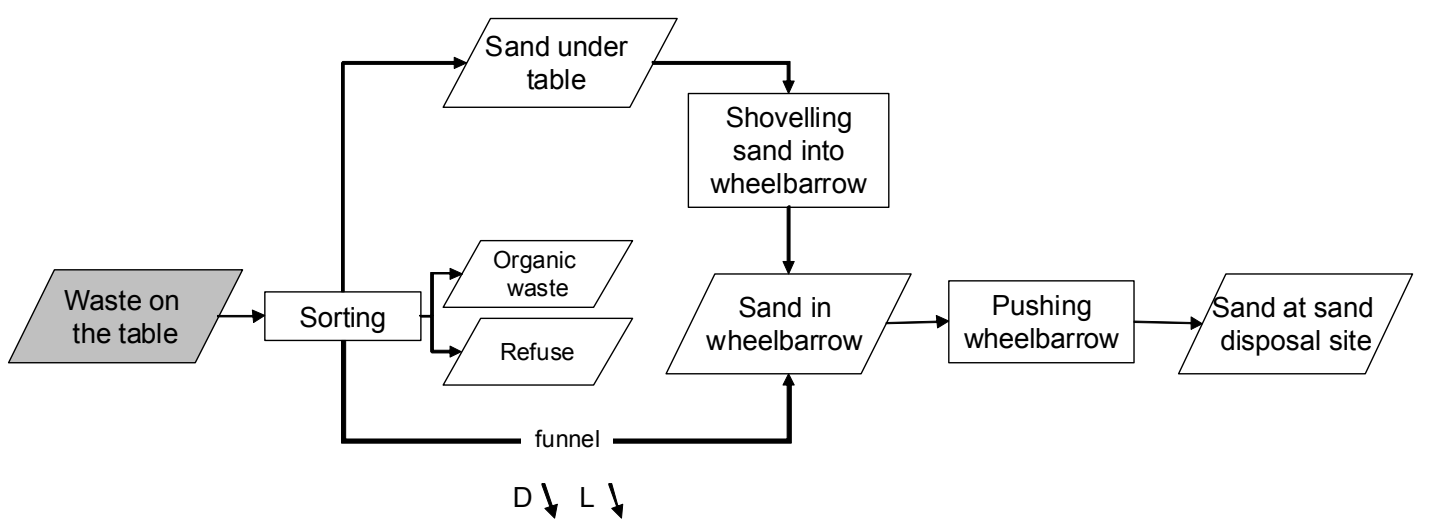

Figure 5. Current and suggested sorting procedures

bold arrow: alternative procedure; at the bottom: Risk reduction by new procedure compared to current one: $\mathrm{D}=$ Dust emissions, $\mathrm{L}=$ Physical load.

The same strategy can be applied to the sieving and packing process. Sieved compost falls directly into sacks placed underneath the sieve. The sacks can be placed into barrels to stabilize the material. If compost had to be provided in larger quantities, it could be collected directly in the barrels which could be transported with a wheeled vehicle to the truck. Alternatively, compost could fall into a wheelbarrow. In that case, guiding the falling compost by a funnel made of plastic or textile, comparable to the suggested solution for the sorting table, would reduce spillage.

Sieving the compost straight into the sack used for customer supply saves five work steps (Figure 6) With each omitted work step, physical workload and exposure to dust is reduced.

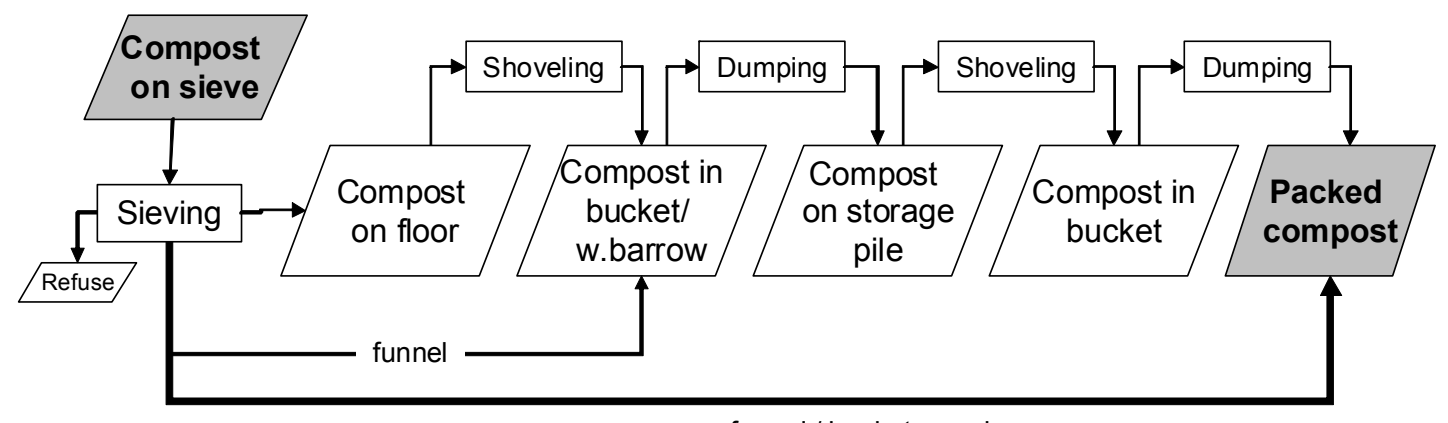

funnel / buckets, sacks

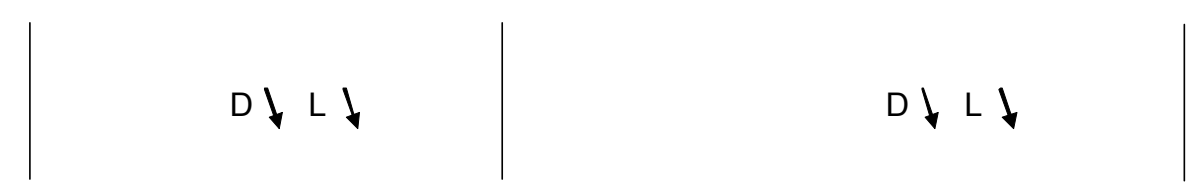

Figure 6. Current and suggested sieving and packing procedures

Bold arrow: Alternative procedure; at the bottom: Risk reduction by new procedure compared to current one: $\mathrm{D}$ = Dust emissions, $\mathrm{L}=$ Physical load, $\mathrm{H}=$ Hazardous substances, $\mathrm{M}=$ Mechanical risks.

In order to avoid the demand for interim storage of large compost quantities it is necessary to establish a regular market for compost. This is a prerequisite for running a sustainably operating enterprise and for the 
implementation of the redesigned sieving and packing process alike. Market development initiatives are in progress.

Table 2. Short-term interventions: organisation and behaviour

\begin{tabular}{lll}
\hline Measure & Benefit & Process \\
\hline Extinguish dumpsite fire immediately & $\begin{array}{l}\text { Reduction of exposure to hazardous } \\
\text { emissions }\end{array}$ & All \\
\hline Alternate tasks & $\begin{array}{l}\text { Reduction of exposure time to dusts, } \\
\text { reduction of risk of physical overload due } \\
\text { to constant carrying }\end{array}$ & All \\
\hline Define walk paths & $\begin{array}{l}\text { Reduction of tripping risks, increase of } \\
\text { psychological wellbeing }\end{array}$ & All \\
\hline Keep the platform clean & $\begin{array}{l}\text { Replacement of carrying with easier } \\
\text { pushing and pulling activities, reduction } \\
\text { wse of wheelbarrows or carts instead of drums } \\
\text { to transport waste and compost }\end{array}$ & $\begin{array}{l}\text { All } \\
\text { transport } \\
\text { processes: }\end{array}$ \\
$\begin{array}{lll}\text { Do not stand in the dust plume created by a } \\
\text { co-worker; go away }\end{array}$ & $\begin{array}{l}\text { Reduction of number of persons exposed to } \\
\text { dust }\end{array}$ & $\begin{array}{l}\text { All } \\
\text { processes }\end{array}$ \\
\hline $\begin{array}{l}\text { Consider wind direction when transferring } \\
\text { waste, pre-compost and sand. Filling and } \\
\text { emptying buckets and wheelbarrows: Stand with } \\
\text { the back to the wind so that dust is blown away } \\
\text { from the body }\end{array}$ & Reduction of exposure to dust \\
$\begin{array}{l}\text { Try to push pre-compost away from the body } \\
\text { when breaking the piles }\end{array}$ & $\begin{array}{l}\text { Reduction of exposure to dust } \\
\text { dust } \\
\text { generation: }\end{array}$ & Turning \\
\hline
\end{tabular}

Adaptation of the composting process itself with regard to occupational risk reduction is problematic without mechanization. Apart from high investment costs, a mechanized pile/windrow turning process would require a reduced number of workers with different qualifications and oppose the goal of ENPRO and GEVALOR to create a high number of work places through valorisation of organic waste. To reduce exposure to dust and physical burdens, a task rotation system should be set up. Turning crews should be allowed frequent breaks in fresh air. During turning, wind can be either a friend or an enemy, depending on its direction in relation the worker: Whenever possible, compost piles or windrows should be arranged in a turning line that considers the main wind direction in a way that allows to worker to stand in the lee, i.e. with the back to the wind so that dust is blown away from the body. Dust masks (FFP2 European standard) should be worn and replaced daily (ABAS, 2007).

The process re-engineering measures described require implementation time and funds. In the short term, organisational and behavioural measures listed in Table 2 can decrease occupational risks to a certain extent. They reduce the time of exposure to dust and facilitate material transport.

Using wheelbarrows for waste disposal and turning away from dust emitting processes were ideas also suggested by the workforce during the onsite workshop. The suggested organisational and behavioural measures were introduced immediately. However, it is not easy to change people's habits and, hence, adoption of the new behaviour is still incomplete. Awareness raising and training sessions are repeatedly performed to promote safer work practices.

General hygienic provisions are required to prevent contamination of private clothes and to avoid exposure to biological agents and other hazardous substances via the oral path. Constructional measures involve showers or washing rooms, separation of the recreation area from the work area and a separate storage of work and leisure clothes ("black/white" areas). A first aid kit needs to be available and replacement of the materials should be organised. It is recommended to vaccinate workers at least against tetanus, else also against Hepatitis B. 
ENPRO's management is highly committed to realise the suggested safety interventions. However, expenditures for the implementation of occupational safety and health measures detailed above had not been considered during the acquisition of external funding which had been carried out before the decision to undertake this study. As a result, most construction and equipment procurement efforts have to be deferred.

Due to municipal decisions, ENPRO needs to relocate the composting facility in 2015 . The new site should preferably be located next to a professionally constructed transfer site and not next to a dumpsite/wild dump to avoid exposure to toxic emissions. Moreover, the infrastructure of the transfer site could be used for disposal of residual waste. Properties of the delivered waste - mixed waste or organic waste separated at household level further define design parameters.

\section{Conclusions}

Workers at small scale pile/windrow composting plants in developing countries are exposed to organic dusts, experience musculoskeletal burdens and are at risk of injuries caused by sharp (contaminated) items. These risks can be reduced by omitting work steps. Good process-reengineering measures address all aforementioned occupational hazards at the same time and contribute to smooth and efficient working procedures. Separation of organic waste from residual waste at household level reduces the demand for waste sorting. Delivery of organic waste fraction separated at household level to the composting facility is highly recommended since it entails the omission of the pre-sorting process and reduces exposure to sharp, infectious materials during the manual sorting procedure.

The concepts developed in this study followed an internationally acknowledged hierarchy which favours substitution of hazardous processes and technical measures. Our suggestions can be applied to any composting facility with comparable pre-conditions or be easily adjusted to varying local situations. Occupational safety and health concerns should be integrated in the design of new composting plants from the beginning, especially as some of the measures require investment expenditures which should be included in financial plans. At existing plants with a lack of funds for the implementation of the construction and procurement suggestions occupational risk reduction can start with work re-organisation

\section{Acknowledgements}

The French associations Gevalor and GoodPlanet are carrying out a project called "Africompost", which started in 2011. It is founded by the French AFD and FFEM and aims at supporting the development of already operational composting units to generate good quality compost and selling carbon credits thus generated by reduction of methane emissions from landfill disposed waste. Another target is to empower the local project partners. The project shall provide environmental and economic as well as social benefits by generating around one hundred new workplaces for persons with a low education level.

The German Federal Institute for Occupational Safety and Health developed occupational safety and health measures and standards for small scale waste management plats in the context of a project called "IGNIS Income generation and climate protection by valorizing municipal solid wastes in a sustainable way in emerging megacities", funded by the German Federal Ministry of Education and Research. To ensure the social sustainability of Gevalor's and GoodPlanet's projects, the French project consortium and BAuA decided to include a study on occupational safety and health in some of the projects by performing a screening study on transferability of methods and results generated in the context of the IGNIS project to selected sites. This paper depicts some results of this study for ENPRO's composting site in Lomé, Togo.

\section{References}

ABAS Ausschuss für Biologische Arbeitsstoffe (Ed.). (2007). Abfallbehandlungsanlagen einschließlich Sortieranlagen in der Abfallwirtschaft (TRBA 214). Gemeinsames Ministerialblatt. Nr. 35. Berlin.

Ale, S., Iampolski, F., Mewezouno L., Samman, M., Tcha-Thom, M., \& Viala, H. (2007). Enquête déchets solides et assainissement à Lomé: Le cas d'Agbalepedogan. Université de Limoges, unpublished.

Bleck, D., \& Wettberg, W. (2012). Waste collection in developing countries - tackling occupational safety and health hazards at their source.Waste Management, 32(2012), 2009-2017. http://dx.doi.org/10.1016/j.wasman.2012.03.025

Bundesanstalt fuer Arbeitsschutz und Arbeitsmedizin (BAuA). (2001). Instructions for Use when Assessing Working Conditions Using the Key Indicator Method for Activities Involving Lifting, Holding, Carrying. Dortmund/Berlin.

Bundesministerium für Arbeit und Soziales. (2006). Merkblatt zu der Berufskrankheit 2108 der Anlage zur 
Berufskrankheitenverordnung. Bekanntmachung des BMAS vom 1. IV-a 4-45222-2108. Bundesarbeitsblatt 10-2006 S. 30ff. Berlin.

Chambers, R. (1994). The Origins and Practice of Participatory Rural Appraisal. World Development, 22, 7.

Cointreau, S. (2006). Occupational and environmental health issues of solid waste management. Special emphasis on middle- and lower-income countries. Urban Papers UP, 2, 1-40.

Deutsches Institut fuer Normung. (2002). DIN EN 1005-3. Safety of machinery - Human physical performance Part 3: Recommended force limits for machinery operation. German version EN 1005-3:2002. Berlin.

Dutkiewicz, J. (1997). Bacteria and fungi in organic dust as potential health hazard. Ann Agric Environ Med., 4, 11-16.

Eerd van, M. (1997). The occupational health aspects of waste collection and recycling. An inventory study in India. UWEP Working Document 4, Part II. Waste, 1-62.

European Economic Community (EEC). (1989). Council Directive 89/391/EEC of 12 June 1989 on the introduction of measures to encourage improvements in the safety and health of workers at work. Official Journal of the European Communities. L 183 , 29/06/1989 P. 0001 - 0008.

European Commission. (Ed.) (2000). Directive 2000/54/EC of the European Parliament and of the Council of 18 September 2000 on the Protection of Workers from Risks Related to Exposure to Biological Agents at Work. (Seventh Individual Directive within the Meaning of Article 16(1) of Directive 89/391/EEC). Official Journal of the European Communities, L262/21-45.

Gevalor. (2012). L'unité de compostage de Lomé (Togo). Retrieved October 30, 2012, fromhttp://www.gevalor.org/projets-compostage/lome-togo.html

Gladding, T., Thorn, J., \& Stott, D. (2003). Organic dust exposure and work-related effects among recycling workers. American Journal of Industrial Medicine, 43(6), 584-591.

Groner-Weber, S. (1999). Arbeitsschutz in der Abfallwirtschaft aus Sicht der ÖTV. Bregau-Institute und Behörde für Arbeit, Gesundheit und Soziales der Freien und Hansestadt Hamburg. (Hrsg.). Arbeitsschutz innovativ: Biologische Arbeitsstoffe und Arbeitsschutz. Band 1, ISBN 3-00-003861-2. Bremen/Hamburg. Page 121 131.

Gruber, Kittelmann, Mierdel. (2008). Leitfaden für die Gefährdungsbeurteilung. 9. Auflage. Verlag Technik und Information. Bochum.

Haan, H. C., Coad, A., \& Lardinois, I. (1998). Municipal solid waste management: Involving micro- and small enterprises. Guidelines for municipal managers. International Training Centre of the ILO, SKAT, WASTE. Turin.

Heldal, K. K., \& Wijnand, E. (2004). Associations between acute symtoms and bioaerosol esposure during the collection of household waste. American Journal of Industrial Medicine, 3, 253 - 260. http://dx.doi.org/10.1002/ajim.20058

Heldal, K., Wijnand, E., \& Bergum, M. (1997). Bioaerosol exposure during handling of source separated household waste. Ann Agric Environ Med, 4, 45-51.

IGNIS consortium. (2011). IGNIS Task 2.1 - Methodology for the Analysis of Pilot Projects. Methodical, systematic and organized process of pilot project analysis. Unpublsihed draft September 2011.

ILO. (1981). Retrieved May 20, 2010, from http://www.ilo.org/global/About_the_ILO/Origins_and_history/lang--en/index.htm

Internationaler Verband für Soziale Sicherheit (IVSS) (Ed.) (1997). Gefahrenermittlung, Gefahrenbewertung, Pasisbewährde systematische Methoden. Heidelberg.

Ivens, U., Breum, N. O., Ebbehoj, N., Nielsen, B. H., Poulsen, O. M., \& Würtz, H. (1999). Exposure-response relationship between gastrointestinal problems among waste collectors and bioaerosol exposure. Scand $J$ Work Environ Health, 3, 238-245. http://dx.doi.org/10.5271/sjweh.430

Koledzi K. E., Matejka G., Ludington G., Baba G., Tchangbedi G., Pilabana A., \& Morizot, G. (2012). Conception, installation et fonctionnement d'une installation décentraliséede tri-compostage de résidus solides urbains dans les quartiers de Lomé. Colloque Eau, Déchets et Développement Durable, 21-24 mars 2012, Agadir, Maroc.

Malmros, P., Sigsgaard, T., \& Bach, B. (1992). Occupational health problems due to garbage sorting. Waste 
Management \& Research, 2, 227-234.

Nielsen, M., Würtz, H., Holst. E., \& Breum, N. O. (1999). Microorganisms and endotoxin in stored biowaste percolate and aerosols. Waste Management and Research 1998, 16, 150-159. http://dx.doi.org/10.1177/0734242X9801600207

Nohl, J., \& Thiemecke, H. (1988). Systematik zur Durchführung von Gefährdungsanalysen, Verlag für neue Wissenschaft $\mathrm{GmbH}$.

Republique, T., Ministère, D. T., \& de l'emploi et de la sécurité sociale. (2006). Loi 2006-10 du 13 Décembre 2006 portant Code du Travail.

Republique Togolaise, Ministère du travail, de l'emploi et de la sécurité sociale. (2011). Loi 2011-006 du 21. février 2011 portant code de sécurité seciale au Togo.

Riege, F. G. (1999). Mikroorganismen beim Umgang mit biologischem Abfall - Messungen und Beurteilungen. In Bregau-Institute und Behörde für Arbeit, Gesundheit und Soziales der Freien und Hansestadt Hamburg. (Hrsg.). Arbeitsschutz innovativ: Biologische Arbeitsstoffe und Arbeitsschutz. Band 1, ISBN 3-00-003861-2. Bremen/Hamburg. Page 143 - 164.

Swida, U. (1999). Risiken und Maßnahmen zum Schutz der Beschäftigten. In Bregau-Institute und Behörde für Arbeit, Gesundheit und Soziales der Freien und Hansestadt Hamburg. (Hrsg.). Arbeitsschutz innovativ: Biologische Arbeitsstoffe und Arbeitsschutz. Band 1, ISBN 3-00-003861-2. Bremen/Hamburg. Page $50-$ 60 .

United Nations. (1948). Human Rights Declaration. G.A. res. 217A (III), U.N. Doc A/810 at 71, adopted by the General Assembly of the United Nations. December 10. Paris.

Yang, C.- Y., Chang, W. - T., Chuang, H. - Y., Tsai, S. - S., Wu, T. - N., \& Sung, F. - C. (2000). Adverse health effects among household waste collectors in Taiwan. Environmental Research Section A, 85, 195-199.

\section{Copyrights}

Copyright for this article is retained by the author(s), with first publication rights granted to the journal.

This is an open-access article distributed under the terms and conditions of the Creative Commons Attribution license (http://creativecommons.org/licenses/by/3.0/). 